\title{
Correction to: Rheology of melts from the Colli Albani Volcanic District (Italy): a case study
}

\author{
Christin Kleest $^{1}$ D . Sharon L. Webb ${ }^{1} \cdot$ Sara Fanara $^{1}$
}

Published online: 10 October 2020

(c) The Author(s) 2020

\section{Correction to: \\ Contributions to Mineralogy and Petrology (2020) 175:82 \\ https://doi.org/10.1007/s00410-020-01720-1}

In the published online version of the paper, the title is:

Rheology of melts from the colli albani volcanic district (Italy): a case study

The corrected title is as followed:

Rheology of melts from the Colli Albani Volcanic District (Italy): a case study

The acknowledgements in the online version of the paper are:

Acknowledgments Open Access funding provided by Projekt DEAL.

The corrected acknowledgments are as followed:

Acknowledgements This research was funded by the Deutsche Forschungsgemeinschaft grant No. WE 1801/15-1. For technical assistance, we wish to thank Bettina SchlieperLudewig for her help at the viscosity and calorimetry measurements and the colorimetric determination of the iron speciation and Marina Horstmann for her help at the chemical analysis at the $\mu$-RFA and the EMP as well as Andre Petitjean for the sample preparation. Furthermore, we wish to thank Dr. Andreas Kronz for the support at the electron microprobe, Dr. Kirsten Techmer for the support at the scanning electron microscope and Dr. Burkhard Schmidt for the discussion of the Raman spectra. We thank the two anonymous reviewers for their constructive suggestions for improvements.

The original article can be found online at https://doi.org/10.1007/ s00410-020-01720-1.

Christin Kleest

christin.kleest@uni-goettingen.de

1 Georg August Universität Göttingen, Abteilung

Experimentelle Mineralogie, Goldschmidtstraße 1,

37077 Göttingen, Germany
Open Access This article is licensed under a Creative Commons Attribution 4.0 International License, which permits use, sharing, adaptation, distribution and reproduction in any medium or format, as long as you give appropriate credit to the original author(s) and the source, provide a link to the Creative Commons licence, and indicate if changes were made. The images or other third party material in this article are included in the article's Creative Commons licence, unless indicated otherwise in a credit line to the material. If material is not included in the article's Creative Commons licence and your intended use is not permitted by statutory regulation or exceeds the permitted use, you will need to obtain permission directly from the copyright holder. To view a copy of this licence, visit http://creativecommons .org/licenses/by/4.0/.

Publisher's Note Springer Nature remains neutral with regard to jurisdictional claims in published maps and institutional affiliations. 